\title{
Authentication of a selected medicinal plants using DNA barcoding technique
}

\author{
Che Nasriyyah Che Husin ${ }^{1}$, Darlina Md. Naim ${ }^{1}$, Mardiana Idayu Ahmad ${ }^{2}$ \\ ${ }^{1}$ School of Biological Sciences, Universiti Sains Malaysia, 11800 Pulau Pinang, Malaysia \\ ${ }^{2}$ School of Industrial Technology, Universiti Sains Malaysia, 11800 Pulau Pinang, Malaysia
}

\begin{abstract}
Plants are valuable source of a medicine and have long being used to cure various ailments. However, the efficacy of drugs derived from plant depends on the reliable identification of correct plants. To avoids the usage of incorrect plant that can cause poisoning, a reliable method than morphological characteristic is required. DNA barcoding technique have shown to be an efficient tool for species identification by using a short fragment of the genomic DNA and has been used widely in molecular plant taxonomy for authentication of medicinal plants species. Thus, the goal of this study was to use DNA barcoding technique to discriminate medicinal plants. DNA samples were extracted from twenty medicinal plants, chosen based on their therapeutic efficacy and were used as templates. Internal transcribed spacer (ITS2) gene was selected to be the best molecular marker for identification purposes. The efficiency of the amplification by polymerase chain reaction was sending for sequencing and species identification was performed using MEGA6. Our findings show that DNA barcoding is an efficient tool for plants identification. This study revealed that medicinal plant and their closely related species can be distinguished by using DNA barcoding technique with ITS2 region as it is an efficient marker and potential DNA marker for authentication of selected plants.
\end{abstract}

\section{Introduction}

Plants have been used as source of medicine for thousands of years by many cultures and there are many publications $[1,6,9,10]$ that highlighted the usage of plants to treat various kinds of diseases. In recent years, traditional herbal medicines have gained popularity as consumers are reportedly more comfortable taking product that are deemed natural, easily available, cheap and are less side effects. Approximately about one-third of commercially drugs in pharmaceutical industry are natural products based origin or their derivatives.

The traditional approach towards discovery of plant based drugs often involved amount of time and expenditure. Traditional approaches for identification of herbal products include organoleptic methods (identification by sense: taste, sight, smell, touch), macroscopic and microscopic methods (identification by shape, colour, texture) [13]. However, in most cases a professional taxonomist is needed. If the specimen is damaged or immature stage of development, even specialist may be unable to identify. Another identification method is by using chemical profiling but it may be affected by physiological and storage conditions. Therefore, there is a need for new approach in an efficient and accurate identification of plant species and their adulterants. Authentication using DNA barcoding overcomes these problems.

DNA barcode is a rapid and accurate identification of any plant species based on extracting a short DNA sequence from a tiny sample of any organism. It allows taxonomists to quickly and accurately recognize species and retrieve information about them. It also allows non-expert to identify species from damaged or industrially processed material. The term DNA barcode for species identification was introduced by Paul Hebert in 2003 (Hebert \& Gregory, 2005). Several potential existing barcoding candidates have been reported such as atpF-atpH, matK, rbcL, $p s b K-p s b I, t r n H-$ $p s b A, y c f 5$ and ITS $[7,11]$. 


\section{Materials and methods}

\subsection{Plant material}

In this study twenty matured fresh leaves of selected medicinal plants were collected. Damaged leaves were sorted out followed by washing with running water to remove the dirt and adherent.

\subsection{DNA preparation, amplification and sequencing}

DNA was extracted from leaves using modified CTAB method [2]. DNA were amplified by polymerase chain reaction (PCR) through 30 cycles of $95^{\circ} \mathrm{C}$ for $2 \mathrm{~min}, 94^{\circ} \mathrm{C}$ for $45 \mathrm{~s}, 47.9^{\circ} \mathrm{C}$ for $45 \mathrm{~s}$ and $72{ }^{\circ} \mathrm{C}$ for $1 \mathrm{~min}$. The primers used were ITS2-F, 5'-GCGATACTTGGTGTGAAT-3' and ITS2- $R$, $5^{\circ}$ '-GACGCTTCTCCAGACTACAAT-3' .The PCR product were run on a $2 \%$ agarose gel in $0.5 \times$ TBE buffer and DNA sequencing was performed by Bioneer Corporation located at Korea using the same amplification primers.

\subsection{Sequence analysis}

Sequencing results was aligned using MEGA6 software [12]. The sequences of the species were blasted with the GenBank database to assess the identification of unknown sequence. The highest-scoring hit of maximum identity from each sample was taken as the barcoding identification. Results were given in Table 1.

\section{Results and discussion}

DNA barcoding have been applied in the field of taxonomy and become popular in the past few years [7]. The technique is a useful tool for taxonomist because rapid and accurate method of species identification is very much important to ensure that the drugs made from medicinal herbs are safe to consume. There is an urgent need to establish a rapid and simple DNA barcoding identification system, since scientist in other field also a potential user of DNA barcodes [14].

Current candidate barcodes are ITS and ITS2 of nuclear ribosomal DNA, as well as psbA-trnH, matK, ycf5, rbcL and rpoC1 in the chloroplast. Previous observations have been shown the potential of ITS2 as a suitable marker for taxonomic classification compared to other barcode markers [15]. In this study, we used internal transcribed spacers 2 (ITS2) as DNA barcodes to identify selected medicinal plants. The ability of routine amplification using a universal primer pair and the generation of unambiguous bidirectional DNA sequences with minimum editing are two major criteria of selecting an ideal DNA barcode. In addition, ITS2 has good primer sites due to the region is short which is easy to amplify and sequence [17].

Results from the study demonstrated that the primer used, ITS2 presents a promising universal DNA barcode to recognize twenty selected medicinal plants by giving high percentage of maximum identity for each sample (Table. 1). However, a few samples showed low percentage of maximum identity below than $95 \%$ which are Pereskia sacharosa, Murraya koenigi (84\%), Piper sarmentosum (88\%), Carica papaya (87\%) and Clinacanthus nutans $(87 \%)$. Maximum identity below than $95 \%$ was rejected because the result shows an ambiguous species identification [5].

Table 1. Sequencing result

\begin{tabular}{|c|c|c|c|}
\hline No & Scientific Name & Vernacular Name & Maximum Identity (\%) \\
\hline 1 & Emilia sonchifolia & Bayam paksi & 98 \\
\hline 2 & Kaempferia galanga & Cekur & 98 \\
\hline 3 & Brucea javanica & Lada pahit & 89 \\
\hline 4 & Pereskia sacharosa & Duri 7 & 99 \\
\hline 5 & Peperomia pellucida & Ketumpang air & 100 \\
\hline 6 & Citrus maxima & Limau bali & 99 \\
\hline 7 & Alpinia galanga & Lengkuas & 99 \\
\hline 8 & Mangifera indica & Mangga & 100 \\
\hline 9 & Amaranthus tricolor & Bayam & \\
\hline
\end{tabular}




\begin{tabular}{|l|c|c|c|}
\hline 10 & Sauropus androgynous & Pucuk manis & 99 \\
\hline 11 & Oenanthe javanica & Selom & 99 \\
\hline 12 & Murraya koenigii & Kari leave & 99 \\
\hline 13 & Averrhoa bilimbi & Belimbing buluh & 100 \\
\hline 14 & Chromalaena odorata & Kapal terbang & 99 \\
\hline 15 & Allium tuberosum & Kucai & 100 \\
\hline 16 & Psidium guajava & Jambu batu & 88 \\
\hline 17 & Piper sarmentosum & Kaduk & 87 \\
\hline 18 & Carica papaya & Betik & 87 \\
\hline 19 & Clinacanthus nutans & Belalai gajah & 100 \\
\hline 20 & Melastoma imbricatum & Keduduk puteh & \\
\hline
\end{tabular}

Maximum identity is an indicator that used to measure the likeliness of identified species. If the maximum identity more than $95 \%$, it is likely to have been correctly identified. Nevertheless, if the closely related species to the identified species in geographical area were not included in the reference database, .even the maximum identity more than $95 \%$, the identity may be incorrect.

The successful of species identification influenced by some factors. First, the quality of yield DNA, the isolation of pure and high molecular weight DNA is critical for the successful application of molecular methods and this can be quite challenge since the DNA is often highly degraded by high temperature. Second, a suitable primer used and third, the sequence quality [8]. The successful rates of DNA sequencing can be relatively low due to the presence of polymorphic DNA in multiple copies [16] and also because the sequences were contaminated by fungal or other parasitic species, such as arthropods and protozoa [4].

\section{Conclusions}

DNA barcoding is a reliable tool for authentication of the selected medicinal plants. In this study, the DNA barcoding with the use of ITS2 from the nucleus gene was highly successful. Therefore, our finding contributed to the previous studies of ITS2 as a potential marker that can be implemented for studying and identifying medicinal plants.

\section{Acknowledgements}

This study was supported by Long Term Research Grant (LRGS) on 'Conceptualizing local knowledge: A study on sustainable values of local wisdom and indigenous science’ (R/LRGS/A02.00/00559A/004/2012/000089).

\section{References}

1. W.W. Chao, B.F. Lin, Chinese Medicine, 5(1), 1 (2010)

2. J.H. Cota-Sánchez, K. Remarchuk, K. Ubayasena, Plant Molecular Biology Reporter, 24(2), 161-167 (2006)

3. P.D. Hebert, T. R. Gregory, Syst Biol, 54(5), 852-859 (2005)

4. P. M. Hollingsworth, S. W. Graham, D. P. Little, PLoS One, 6(5), e19254 (2011)

5. A. Kool, H. J. De Boer, A. Kruger, A. Rydberg, A. A. Abbad, L. Bjork, G. Martin,PLos One, 7, e39459 (2012)

6. S. Y. Lin, C. C. Wang, Y. L. Lu, W. C. Wu, W. C Hou, Food and Chemical Toxicology, 46(7), 2485-2492 (2008)

7. K. Luo, S. Chen, K. Chen, J. Song, H. Yao, X. Ma, X. Li, Science China Life Sciences, 53(6), 701-708 (2010)

8. P. Mahadani, S. K. Ghosh, DNA Barcodes, 1, 35-38 (2013)

9. T. Nalina, Z. Rahim, Am J Biotechnol Biochem, 3(1), 10-15 (2007)

10. M. J. Oh, M. A. Hamid, S. Ngadiran, Y. K. Seo, M. R. Sarmidi, C. S. Park, Archives of dermatologicalresearch, 303(3), 161-170 (2011)

11. X. Pang, J. Song, Y. Zhu, C. Xie, S. Chen, Planta medica, 76(15), 1784-1786 (2010)

12. K. Tamura, G. Stecher, D. Peterson, A. Filipski, S. Kumar, Mol Biol Evol, 30(12), 2725-2729 (2013)

13. N. Techen, I. Parveen, Z. Pan, I. A. Khan, Current Opinion in Biotechnology, 25, 103-110 (2014)

14. M. W. Chase, N. Salamin, M. wilkinson, J. M. Dunwell, R. P. Kesanakurthi, Philosophil Transactions of The Royal Society B, 360, 1889-1895 (2005) 
15. A. W. Coleman, Trends in Genetics, 19, 370-375

16. I. Alvarez, J. F. Wendel, Molecular Phylogenetics and Evolution, 29(3), 417-434 (2003)

17. W. J. Kress, K. J. Wurdack, E. A. Zimmer, L. A. Weight, D. H. Janzen, The National Academy of Sciences, 102, 8369 (2005) 